\title{
DNA sequence determination and biochemical analysis of the immunogenic protein P36, the lactate dehydrogenase (LDH) of Mycoplasma hyopneumoniae
}

\author{
Andreas Haldimann, JaCQues Nicolet and Joachim FreY* \\ Institute for Veterinary Bacteriology, University of Berne, Länggassstrasse 122, CH-3012 Berne, Switzerland
}

(Received 2 September 1992; revised 2 October 1992; accepted 26 October 1992)

\begin{abstract}
The DNA sequence of the gene encoding the early and specific immunogenic protein P36 of Mycoplasma hyopneumoniae has been determined. Comparison of the DNA sequence and the deduced amino acid sequence of P36 with known genes and proteins in data banks indicated that P36 is a L-lactate dehydrogenase (LDH) (EC 1.1. 1.27). Biochemical analysis of protein $P 36$ expressed from the cloned gene in Escherichia coli confirmed that P36 has L-lactate dehydrogenase activity. Protein P36 of $M$. hyopneumoniae therefore is termed LDH and its gene Idh. M. hyopneumoniae LDH was shown to contain the typical domains of LDH of other bacterial species. Immunologically however, we have shown that polyclonal antibodies against $M$. hyopneumoniae LDH do not crossreact with related LDH and show high specificity for $M$. hyopneumoniae. The ldh gene is preceded by several typical -10 sequences found in promoters of prokaryotes, but lacks the -35 sequence. Sequences rich in $A+T$, however, precede the -10 boxes, suggesting that factors involved in transcription initiation and their regulation may be different in $M$. hyopneumoniae compared to other bacterial species, but the putative ribosome binding site seems to be conserved.
\end{abstract}

\section{Introduction}

Mycoplasma hyopneumoniae is the primary agent of enzootic porcine pneumonia one of the most important direct or indirect causes of porcine respiratory infectious disease (Ross, 1992). It is spread worldwide and causes large economic losses in swine production units through retarded growth, poor food conversion and susceptibility of swine to infection by other organisms (Ross, 1992). The mechanisms of pathogenicity and the virulence factors involved in $M$. hyopneumoniae infections are very poorly understood due to the tedious growth procedures and lack of biochemical and genetic data on the organism. Potent immunogenic proteins that might be involved in pathogenicity were detected by immunoblot analysis using convalescent pig serum from naturally or experimentally infected pigs (Young \& Ross, 1987; Mori

*Author for correspondence. Tel. +41312744 84; fax +413124 69 22; email jfrey@vbi.unibe.ch.

\section{Abbreviation: LDH, lactate dehydrogenase.}

The nucleotide sequence data reported in this paper have been submitted to GenBank and have been assigned the accession number X67286. et al., 1988; Strasser et al., 1991) and were named according to their molecular masses because the biochemical functions and structures of these proteins were initially unknown. Protein P54, a $54 \mathrm{kDa}$ protein, was shown to be a cytopathic factor (Geary \& Walczak, 1985 ), P74, a $74.5 \mathrm{kDa}$ protein, was claimed to be a heatshock protein (Brooks \& Faulds, 1989), P65 was identified as a $65 \mathrm{kDa}$ lipoprotein (Kim et al., 1990) and $\mathrm{P} 36$, an early and strongly immunogenic $36 \mathrm{kDa}$ intracellular protein which was cloned and expressed in $E$. coli (Strasser et al., 1991) was shown to be highly speciesspecific (Stipkovits et al., 1991). No sequence data of these proteins or their genes and no knowledge of the sequences involved in their expression are known. The only $M$. hyopneumoniae sequence data available up to now have been of rRNA genes which indicate that promoters of $M$. hyopneumoniae seem to be different from other mycoplasmas (Taschke \& Herrmann, 1986; Taschke et al., 1986, 1987), and two repeated sequences (Ferrell et al., 1989; Harasawa et al., 1991).

A better knowledge of the functions and nature of predominant antigens of $M$. hyopneumoniae and the regulation of their expression are required if their functions in pathogenicity are to be understood. This knowledge is also relevant for the use of such antigens in 
serological differentiation of porcine Mycoplasma species and for the evaluation of their use as ingredients in vaccines. In this report we describe the DNA sequence of the gene encoding the early immunogenic protein P36 and the enzymic, biochemical and immunogenic properties of P36 and compare these properties with those of related proteins of other bacterial species.

\section{Methods}

Organisms and growth conditions. M. hyopneumoniae NCTC 10110 ( $\mathrm{J}^{\mathrm{T}}$ strain) (Rose et al., 1979) was grown in liquid Friis medium (Friis, 1971) and on solid Friis medium supplemented with $0.8 \%$ Ionagar (Oxoid no. 2).

Plasmid pJFF631, which contains a $1.4 \mathrm{kbp}$ chromosomal fragment of $M$. hyopneumoniae in the vector pBluescript II SK ${ }^{-}$(Stratagene) expresses the full length $M$. hyopneumoniae P36 protein (Strasser et al., 1991). Transcription of the P36 gene occurs from the inducible lac promoter of the vector; P36 is translated from the normal ribosome binding site of the gene (Strasser et al., 1991). The $1.4 \mathrm{kbp} M$. hyopneumoniae DNA insert of pJFF631 was subcloned with suitable restriction enzymes into pBluescript II $\mathrm{SK}^{-}$to generate clones for sequencing. $E$. coli XL1-blue endA hsdR17 supE44 lambda ${ }^{-}$recAl $\Delta$ (proAB-lac) $\left[\mathrm{F}^{\prime}\right.$ proAB lac I' $\left.Z \Delta \mathrm{M} 15 \mathrm{Tn} 10\left(\mathrm{Tc}^{\mathrm{r}}\right)\right]$ (Bullock et al., 1987) containing different subclones of the P36 gene were grown in LB broth (Sambrook et al., 1989) supplemented with $25 \mu \mathrm{g}$ ampicillin $\mathrm{ml}^{-1}$. Induction of the lac promoter was obtained by adding $0 \cdot 1 \mathrm{~mm}$ (final concentration) isopropyl- $\beta$-D-thiogalactoside (IPTG) to cultures at an $\mathrm{OD}_{650}$ of 0.2 and subsequent growth to an $\mathrm{OD}_{650}$ of 0.7 . Bacillus stearothermophilus NCTC 10339 (NCIB 8923 ${ }^{\mathrm{T}}$ ) was cultured on blood agar plates at $50^{\circ} \mathrm{C}$. The cells were collected from the surface by resuspension in $0.9 \% \mathrm{NaCl}$.

Growth and metabolism inhibition tests. The growth inhibition test was performed essentially as described by Clyde (1983) on solid Friis medium. After $7 \mathrm{~d}$ of incubation the distance between the antiserum disk and the nearest colonies was measured. Zones of inhibition larger than $1.5 \mathrm{~mm}$ were considered significant.

The metabolism inhibition test was performed according to TaylorRobinson (1983). $M$. hyopneumoniae cells $\left(10^{3}\right.$ colour-changing units per well) were incubated in $200 \mu$ l Friis medium supplemented with test serum at various dilutions. After $3 \mathrm{~d}$ at $37^{\circ} \mathrm{C}$ the highest dilution without colour change was determined and compared to wells containing control sera.

Immunoblot analysis. SDS-PAGE, transfer of proteins to nitrocellulose filters and immunological detection of proteins using polyclonal, monospecific anti-P36 antibodies (Stipkovits et al., 1991) were performed using standard protocols (Sambrook et al., 1989).

$L D H$ activity. Cell extracts were obtained by sonication with a Branson sonifier and subsequent centrifugation for $20 \mathrm{~min}$ at $20000 \mathrm{~g}$ and $4{ }^{\circ} \mathrm{C}$. LDH activity was measured with a commercial test (Merck 3349). Cell extracts $(10 \mu \mathrm{l})$ containing 0.5 to $7 \mu \mathrm{g}$ protein were mixed with $500 \mu$ reaction solution $(0.6 \mathrm{~mm}$-sodium pyruvate; $0.18 \mathrm{~mm}$ $\mathrm{NADH} ; 50.0 \mathrm{~mm}$-phosphate buffer $\mathrm{pH} 7.5)$ and the decrease in NADH was followed at room temperature by measuring the change in $\mathrm{OD}_{340}$.

Protein concentration was determined by the Bio-Rad protein assay. Enzyme activities are given in units $(\mathrm{mg} \text { protein })^{-1}(1 \mathrm{U}=1 \mu \mathrm{mol}$ NAD produced $\min ^{-1}$ ).

$D N A$ and protein sequence analysis. The dideoxy chain-termination method (Sanger et al., 1977) was performed using $\left[{ }^{35}\right.$ S]dATP and $T_{7}$ DNA polymerase with Sequenase sequencing kit (United States
Biochemical) for the direct sequencing of double-stranded plasmid DNA (Zhang et al., 1988). $\mathrm{T}_{3}$ primer 5'-AATTAACCCTCACTAAAGGG-3', and $T_{7}$ primer 5'-TAATACGACTCACTATAGGG-3' were used, in order to ensure that both strands were completely sequenced.

The computer programs PC/Gene (IntelliGenetics, University of Geneva) and the GCG sequence analysis software package (University of Wisconsin, Biotechnology Center) were used for assembly of the DNA sequence and analysis of DNA and protein sequences as well as for comparison of the sequences with the Swiss-Prot and the EMBL data banks.

Sequencing of the $12 \mathrm{~N}$-terminal amino-acid residues of purified recombinant P36 was achieved with a gas-phase sequencer (Applied Biosystems $477 \mathrm{~A}$ ). For this procedure, 200 pmol protein P36 were attached to ProBlot membrane (Applied Biosystems).

\section{Results}

\section{Sequence analysis of the gene encoding protein P36}

The DNA insert of plasmid pJFF631 specifying P36 (Strasser et al., 1991) was sequenced by subcloning the restriction enzyme fragments (Fig. 1) into vector pBluescript II SK ${ }^{-}$. The 1394 bp DNA sequence is shown in Fig. 2. It contains two open reading frames (ORF) in the direction of transcription of P36 (Strasser et al., 1991), one encoding a complete protein of 315 amino acids (ORF1), and a second (ORF2) encoding a 49 amino acid C-terminal polypeptide fragment. ORF1 encodes a polypeptide with a computed molecular mass of $34.2 \mathrm{kDa}, \mathrm{pI}=8 \cdot 12$, and a charge of $1 \cdot 11$ at $\mathrm{pH} 7 \cdot 0$, which represents the $\mathrm{P} 36$ protein. It is preceded by a consensus sequence for a putative ribosome binding site (Shine-Dalgarno sequence) (Shine \& Dalgarno, 1974) 11 bp upstream from the ATG initiation codon. To confirm the identity of the translated polypeptide of ORF1 with P36, protein P36 was expressed from plasmid pJFF631 by induction with IPTG in E. coli strain XL1-blue and purified from a polyacrylamide gel after electrophoresis for amino acid sequence analysis. The sequence of the first 12 amino acid residues of protein P36 were identical to the first 12 amino acid residues deduced from ORF1 (Fig. 2) confirming that ORF1 encodes P36. The G+C content of ORF1 $(34.7 \%)$ is slightly higher than that of the complete chromosome which is $33 \%$ (Stemke et al., 1985). ORF1 stops with codon UAA and does not contain UGA codons in the reading frame [specifying tryptophan in mycoplasmas, (Yamao et al., 1985) but which is a translation stop signal (opal) in E. coli]. Upstream of ORF1, three consensus sequences for -10 boxes of transcription promoters are found preceded by $\mathrm{A}+\mathrm{T}$-rich segments. However, no consensus sequence for a -35 box is present. Both at the end of ORF1 and of ORF2, sequences that can encode mRNA structures very similar to rho-independent transcription stop signals of procaryotes were found (Fig. 2). The calculated stabilities of these RNA secondary structures have $\Delta \mathrm{G}$ 


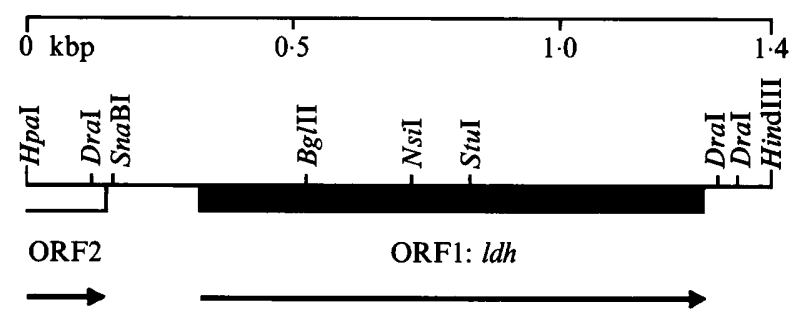

Fig. 1 Restriction endonuclease map of the $1.4 \mathrm{kbp} \mathrm{M}$. hyopneumoniae DNA insert in vector pJFF631. Filled box, ldh gene (P36); open box, $\mathrm{C}$-terminus of ORF2; arrows, direction of transcription.

values of $-58.2 \mathrm{~kJ} \mathrm{~mol}^{-1}$ for the 'hairpin' preceding the -10 boxes and $-71.6 \mathrm{~kJ} \mathrm{~mol}^{-1}$ for the 'hairpin' downstream of ORF1 as calculated by the method of Tinoco et al. (1973).

Computer-assisted searches for homologous proteins using the Swiss-Prot and EMBL databases showed significant sequence identities and similarities between protein P36 and all known L-lactate dehydrogenases (LDH) (EC 1.1.1.27) from various species (Table 1) indicating that P36 is the LDH of Mycoplasma hyopneumoniae. In particular we have found $70 \%$ identity of amino acid residues of P36 to the sites involved in enzymic activity of LDH from prokaryotes (Hensel et al., 1983).

\section{Biochemical and immunological properties of $M$. hyopneumoniae $\mathrm{LDH}$}

To confirm protein $\mathrm{P} 36$ as the L-lactate dehydrogenase of $M$. hyopneumoniae, LDH activity of the lysates from $E$. coli strains containing the cloned P36 gene or the vector alone were made using a commercial test measuring oxidation of NADH to $\mathrm{NAD}^{+}$in the enzymic reduction of pyruvate to L-lactate. $E$. coli strain XL1-blue containing the pBluescript II SK ${ }^{-}$vector alone had an LDH activity of $0.05 \pm 0.03 \mathrm{U}$ (mg protein $)^{-1}$ independent of whether IPTG, the inducing agent of the lac promoter on the vector, was present in the culture or not. The same $E$. coli host strain containing plasmid pJFF631 (encoding P36) had a LDH activity of $0.38 \pm 0.05 \mathrm{U}$ (mg protein) $^{-1}$ without induction, and $7 \cdot 1 \pm 0.3 \mathrm{U}(\mathrm{mg}$ protein) $)^{-1}$ after induction of the vector promoter with IPTG, which represents a 120 -fold increase compared to the strain with the vector alone and which corresponds to the strong increase of the $36 \mathrm{kDa}$ protein seen on SDS gels after IPTG induction. These results confirm that $M$. hyopneumoniae protein P36 is L-lactate dehydrogenase (LDH) and its corresponding gene is therefore termed $l d h$.

Protein P36 (LDH) was shown to be immunologically highly specific for the species $M$. hyopneumoniae and showed no serological cross-reactions with Mycoplasma flocculare or other closely related mycoplasmas (Stipkovits et al., 1991) which is surprising for a common (housekeeping) enzyme. In order to verify the species specificity of $M$. hyopneumoniae $\mathrm{LDH}$, we used the immunoblot technique to analyse total proteins of Bacillus stearothermophilus (which is known to produce LDH with sequence similarity to LDH of $M$. hyopneumoniae) (Table 1), pure LDH type $\mathrm{H}$ from pig, total proteins of $M$. hyopneumoniae and recombinant P36 from E. coli containing plasmid pJFF631 with polyclonal anti-P36 antibodies (data not shown). On the immunoblots, a $36 \mathrm{kDa}$ band appeared in $M$. hyopneumoniae and E. coli containing pJFF631; whereas no reaction was found with $E$. coli containing the vector alone, Bacillus stearothermophilus, or with pure LDH type $\mathbf{H}$ from pig.

To investigate whether antibodies directed against LDH can inhibit growth of $M$. hyopneumoniae, growth and metabolism inhibition tests of $M$. hyopneumoniae were performed. Polyclonal anti-LDH antibodies raised in rabbits did not inhibit growth and metabolic fermentation activity of $M$. hyopneumoniae in culture medium, while rabbit antibodies made against whole cells of $M$. hyopneumoniae showed inhibitory effects in both tests, indicating that anti-LDH antibodies cannot stop or reduce growth of $M$. hyopneumoniae.

\section{Discussion}

DNA sequence analysis of the gene encoding the early and strongly immunogenic protein P36 of $M$. hyopneumoniae revealed that this polypeptide is an L-lactate dehydrogenase (LDH). Amino acid sequence comparisons revealed that the most closely related LDH are those from the Bacilli (Table 1) known to be phylogenetically related to mycoplasmas (Weisburg et al., 1989). Bacterial LDH, however, show distinct differences even between closely related species in contrast to LDH from vertebrates that are closely related (Table 1). We have analysed the amino acid sequence of the hexapeptides of the major putative immunogenic epitope of bacterial LDH. The results (Table 1) show that these domains, in contrast to the domains of the active centres (Hensel et al., 1983), strongly differ among different bacterial species even when they are closely related. This supports earlier observations which showed that $M$. hyopneumoniae $\mathrm{LDH}$, originally termed $\mathrm{P} 36$, is highly species-specific in its immunogenic reaction and can be used for immunological species identification (Stipkovits et al., 1991). At the DNA sequence level, however, differences are less pronounced since cross-hybridization of the $M$. hyopneumoniae ldh gene could be observed with a fragment of chromosomal DNA supposed to contain the $l d h$ gene of the related porcine Mycoplasma flocculare 


$\begin{array}{rrrrr} & 20 & 40 & 60 & 80 \\ \text { HpaI } & 1 & 1 & 1 & 1\end{array}$

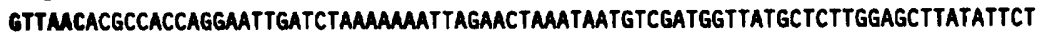

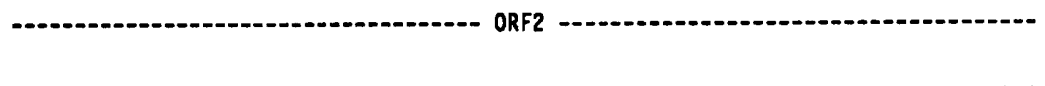

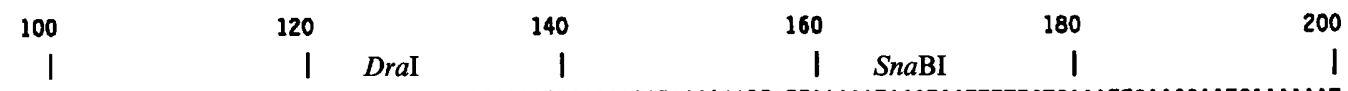

CATTATTATTTTCTCACTTGTTTCTTCMATTGGTTAATGCCCTTTTMMGGAACCAAATCCAGAATATMAMAATTATTAAAATACGTAGTTTTTCTGAAATTGMGGMATCAAAAAAT ORF2

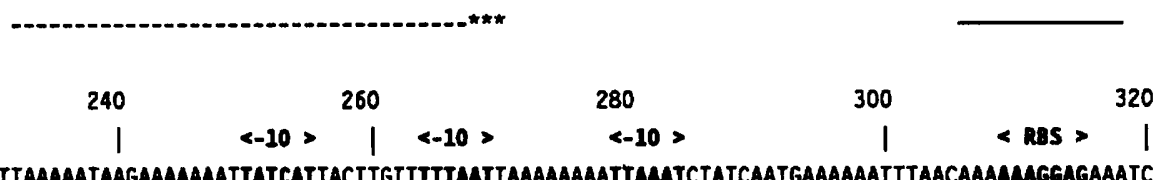

AAAAMAAATTTCATTTITGATTCGTTITAATTAAMAATAAGAAMAMATTATCATTACTTGTTTTTMTTMAAMAAMTTMMATCTATCAATGAAAAAATTTAACAAMMMGGAGAAATC

$\rightarrow$

$\begin{array}{rrrrrr}340 & 360 & 380 & 400 & 420 & 440 \\ \text { I } & 1 & I & 1 & 1\end{array}$

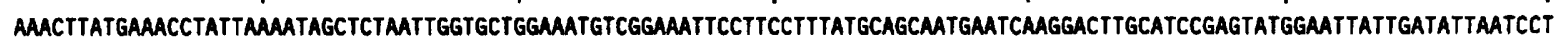

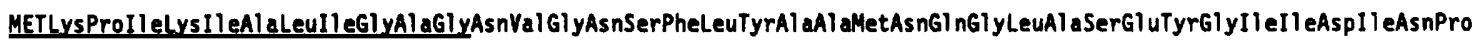

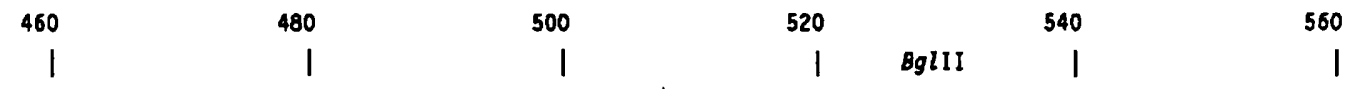

GATTTTGCCGATGGTATGCTTTIGATTTTGAAGATGCCTCAGCTTCTTTGCCTTTTCCGATTAGTGTCTCCCGTTATGAATATAMGATCTAAAAGATGCTGATTTTATTGTAATTACA

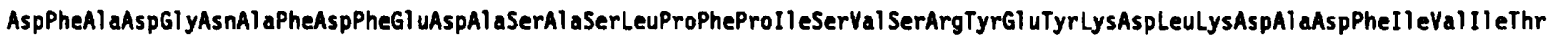

$\begin{array}{rrrrrr}580 & 600 & 620 & 640 & 660 & 680 \\ 1 & 1 & 1 & 1 & 1\end{array}$

GCGGGAAGACCACAAAAACCGGGTGAAATCGGCTTGAATTAGTAGCTGATAACATCCGAATTATCCGgGAMATTGCACTAAAAGTCAAAGAAAGTGGCTTTAGTGGAATAAGTATTATT

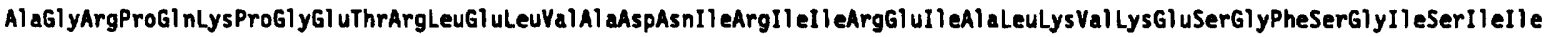

$\begin{array}{rrrrrr}700 & 720 & 740 & 760 & 780 & 800 \\ \text { I } & \text { I NSiI } & \text { I } & \text { I } & \text { I }\end{array}$

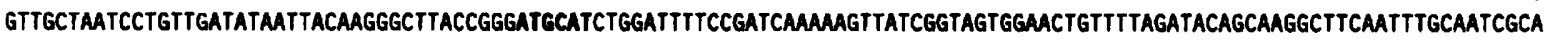

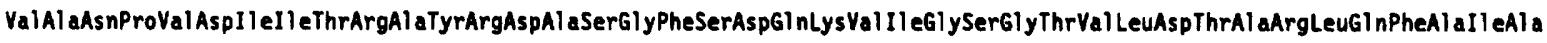

\begin{tabular}{rrrrrr}
820 & 840 & 860 & 880 & 900 & 920 \\
\hline & StuI & 1 & 1 & 1 & 1
\end{tabular}

AAAGAGCAAAAGTATCGCCTAATTCGGTTCAGGCCTACGTGATGGGTGACATGGTGATTCATCTTTTGTTGCTTATTCAAATATTAAAATTGCCGGTGAATGITTCTGTGCTTATTCT

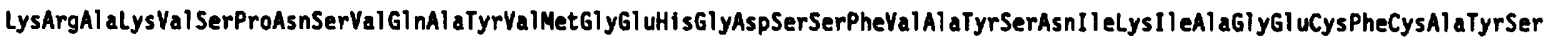

$\begin{array}{rrrrrr}940 & 960 & 980 & 1000 & 1020 & 1040\end{array}$

MACTAACCGGAATTGATAGCTCAAATTACGAAAAAGAACTTGAATATCCAGTTTCTCGCCGGGCTTATGMATTATTMATCGTMAAGGGCAACATTTTATGGAMTTGGTGCAGCTATT

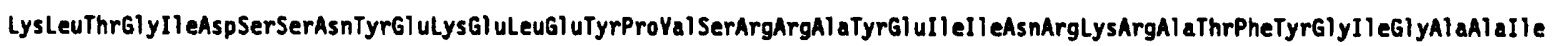

\begin{tabular}{|c|c|c|c|c|c|}
\hline 1060 & 1080 & 1100 & 1120 & 1140 & 1160 \\
\hline 1 & 1 & I & 1 & 1 & \\
\hline
\end{tabular}

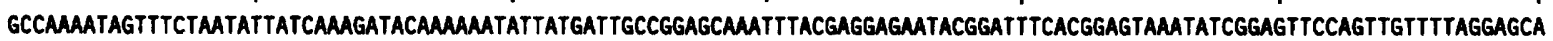

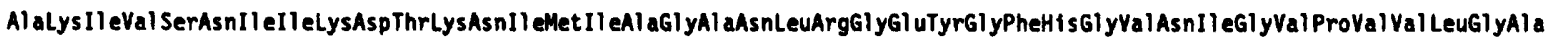

$\begin{array}{rrrrrr}1180 & 1200 & 1220 & 1240 & 1260 & 1280 \\ 1 & 1 & I & 1 & 1 & 1\end{array}$

AaCGgAATTGAAAAMTTATTGAGATTAGTCTTAMTGATAMAgAAMAGAAAATTTGCCAAATCAGTTGCAATCATTGATMAATTTATCAGGATGCAATTAAMMTATTTMTTTITT

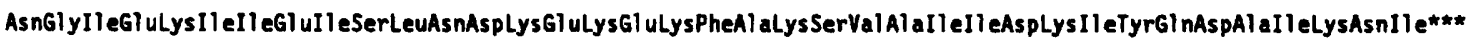

$$
\begin{array}{rrrrrr}
1300 & 1320 & 1340 & 1360 & 1380 & 1394 \\
\text { DraI I } & \text { I } & \text { DraI I } & \mid & \text { I } & \text { HindIII }
\end{array}
$$

AgGAAAACAGTTTMAAATCTCTCTATAAATTTMATATTITTATCCTATGATTTTAMAAAGTACTATAAATTTATAGTACTTTTTTAATTTTTAGCAAAAAAATTGMAGCTT 
Table 1. Sequence similarities and major immunogenic epitopes of L-lactate dehydrogenase from various species

Numbers 1-10 in the top line indicate the same species as the bold numbers on the vertical line right. The values are given in \% identity (upper figures) or \% similarity (lower figures) of the protein sequence calculated according to Needleman \& Wunsch (1970). The hexapeptide of the putative major immunogenic epitope (shown in the right column in the amino acid one letter code) was computed from the amino acid sequences using the method of Hopp \& Woods (1981).

\begin{tabular}{|c|c|c|c|c|c|c|c|c|c|c|c|c|}
\hline 1 & 2 & 3 & 4 & 5 & 6 & 7 & 8 & 9 & 10 & No. & Species (Ref.) & Epitope \\
\hline $\begin{array}{l}41 \\
55\end{array}$ & $\begin{array}{l}39 \\
54 \\
90 \\
93\end{array}$ & $\begin{array}{l}39 \\
53 \\
67 \\
78 \\
67 \\
78\end{array}$ & $\begin{array}{l}41 \\
54 \\
48 \\
59 \\
48 \\
59 \\
46 \\
58\end{array}$ & $\begin{array}{l}33 \\
53 \\
29 \\
42 \\
28 \\
41 \\
26 \\
42 \\
40 \\
60\end{array}$ & $\begin{array}{l}34 \\
52 \\
30 \\
43 \\
29 \\
41 \\
27 \\
42 \\
39 \\
59 \\
87 \\
91\end{array}$ & $\begin{array}{l}28 \\
44 \\
31 \\
48 \\
31 \\
50 \\
33 \\
50 \\
38 \\
57 \\
28 \\
48 \\
29 \\
47\end{array}$ & $\begin{array}{l}28 \\
44 \\
31 \\
48 \\
32 \\
50 \\
33 \\
49 \\
37 \\
56 \\
28 \\
47 \\
28 \\
47 \\
96 \\
98\end{array}$ & $\begin{array}{l}24 \\
38 \\
34 \\
52 \\
34 \\
53 \\
35 \\
51 \\
38 \\
57 \\
33 \\
52 \\
33 \\
51 \\
76 \\
86 \\
75 \\
86\end{array}$ & $\begin{array}{l}23 \\
38 \\
34 \\
52 \\
35 \\
53 \\
33 \\
51 \\
40 \\
58 \\
33 \\
51 \\
34 \\
51 \\
76 \\
85 \\
75 \\
85 \\
92 \\
96 \\
100 \\
100\end{array}$ & $\begin{array}{r}2 \\
3 \\
4 \\
5 \\
6 \\
7 \\
8 \\
9 \\
10\end{array}$ & $\begin{array}{l}\text { M. hyopneumoniae } \\
\text { B. stearothermophilus } \\
\text { (Wirz et al., 1983) } \\
\text { B. caldotenax } \\
\text { (Zülli et al., 1987) } \\
\text { B. subtilis } \\
\text { (Hediger et al., 1986) } \\
\text { L. casei } \\
\text { (Hensel } \text { et al., 1983) } \\
\text { T. aquaticus } \\
\text { (Ono et al., 1990) } \\
\text { T. caldophilus } \\
\text { (Kunai et al., 1986) } \\
\text { Human H } \\
\text { (Sakai et al., 1987) } \\
\text { Pig H } \\
\text { (Kiltz et al., 1977) } \\
\text { Human M } \\
\text { (Tsujibo et al., 1985) } \\
\text { Pig M } \\
\text { (Kiltz et al., 1977) }\end{array}$ & $\begin{array}{l}\text { DKEKEK } \\
\text { DDEKNR } \\
\text { DEEEKK } \\
\text { EKEKEQ } \\
\text { DHEEES } \\
\text { NEEERQ } \\
\text { SPEERE } \\
\text { KLKDDE* } \\
\text { KLKDDE* } \\
\text { DKDKEQ* } \\
\text { TDADKE* }\end{array}$ \\
\hline
\end{tabular}

* Epitope not located congruently with those of prokaryotic LDHs.

(J. Frey, unpublished observations). The ldh gene is therefore not suitable as a gene probe for detection of M. hyopneumoniae

LDH activity seems to be common to mycoplasmas including $M$. hyopneumoniae (Manolukas et al., 1988) which produces in culture conditions a LDH activity of $217 \pm 2 U$ (mg protein) $)^{-1}$. At first glance, it seems surprising that $M$. hyopneumoniae LDH is an early and strongly immunogenic protein in naturally or experimentally infected pigs. LDH is not generally known to be directly involved in pathogenicity mechanisms. Its function is the enzymic conversion of pyruvate to lactate which is the major step for the regeneration of NAD (Garvie, 1980). In E. coli and other enteric bacteria LDH is induced at low pH (Slonczewski et al., 1987; Fairoz et al., 1989). This regulation seems to be very similar to the regulation of expression of stress proteins which are thought to be strongly induced in pathogenic bacteria at certain critical steps of infection (Slonczewski et al., 1987; Foster, 1991). Although LDH is not known to be a bacterial stress protein, one can speculate that the presence of relatively large amounts of this protein might be crucial for $M$. hyopneumoniae for a specific step during infection. To achieve this, the $l d h$ gene might be induced under certain conditions. The relatively strong immunogenic reaction of this protein in the infected animal could be a response to such an induction of $\mathrm{LDH}$ in $M$. hyopneumoniae at an early stage of infection. The LDH of $M$. hyopneumoniae formerly known as P36, has been shown to be located intracellularly (Strasser $e t$ al., 1991), as is LDH of other bacterial species. It is therefore expected that antibodies raised against LDH do not inhibit growth or metabolic activity of $M$. hyopneumoniae as was confirmed experimentally. The protein therefore is most unlikely to induce protective immunity. It is, however, an interesting tool for further studies of bacteria-host interactions and is expected to be useful for serological analysis of early stages of $M$. hyopneumoniae infection.

The $l d h$ gene is the first gene encoding a protein with a known function that has been sequenced in $M$. hyopneumoniae. As expected from previous results, $M$.

Fig. 2. DNA sequence of the $l d h$ gene of $M$. hyopneumoniae and the deduced amino acid sequence of the encoded protein. The restriction enzyme sites used for subcloning are given. Possible -10 regions are indicated by $<-10>$, and the ribosome binding site by $<$ RBS $>$. The putative transcription termination signals are shown by arrows. Symbols: ---, open reading frame $2 ;^{* * *}$, translation stop. The 12 amino acid residues sequenced from protein P36 at the N-terminus are underlined. 
hyopneumoniae LDH is expressed as a full length polypeptide in $E$. coli hosts confirming that no internal UGA codons which are known in mycoplasmas to encode $\operatorname{trp}$ (Yamao et al., 1985) are used. In addition, the coding sequence of $l d h$ is preceded by a RBS which shows good complementarity to the $3^{\prime}$ end of the 16S RNA from $E$. coli (Shine \& Dalgarno, 1974) and from $M$. hyopneumoniae (Taschke et al., 1987), and which seems to be conserved not only in mycoplasmas (Klinkert et al., 1986) but in all bacterial species. The putative transcription promoter of the $M$. hyopneumoniae ldh gene, however, seems to be different from promoters found in other bacteria. The sequence data revealed three possible -10 consensus sequences (Pribnow box) which are not preceded by the typical -35 sequences which are commonly found in bacterial promoters (Rosenberg \& Court, 1979). Characteristic for the region upstream of the -10 boxes is an A+T-rich stretch. A similar finding has been made for the promoter of an unknown $M$. hyopneumoniae gene (Klinkert et al., 1986) and for the promoter of the operon encoding the 16S and 23S rRNA genes of $M$. hyopneumoniae (Taschke \& Herrmann, 1986). This new type of promoter, however, is not common to mycoplasmas or other bacteria and has been found thus far only in $M$. hyopneumoniae. It remains still to prove whether the $\mathrm{A}+\mathrm{T}$-rich sequences replace the -35 region in $M$. hyopneumoniae promoters. The DNA sequence data currently available are limited and do not yet allow description of a consensus sequence for $M$. hyopneumoniae specific promoters. The sequence data in Fig. 2 show that the $l d h$ gene and its putative promoter sequences are flanked by inverted repeat sequences followed by $\mathrm{T}$ residues. These 'hairpin' sequences can encode mRNA structures very similar to rho-independent transcription stop signals of other prokaryotes and suggest that the $l d h$ gene in $M$. hyopneumoniae is encoded on a monocistronic operon. In $E$. coli, one of these putative transcription stop signals, located upstream of $l d h$ is not recognized as such since the $l d h$ gene on plasmid pJFF631 is transcribed from the vector's lac promoter (Strasser et al., 1991) which is located upstream from the 'hairpin' sequences found to precede the $l d h$ gene.

In summary, we have shown that P36 of $M$. hyopneumoniae is an L-lactate dehydrogenase. The role of LDH in pathogenicity of $M$. hyopneumoniae is not known, but the strong immunogenic character of this 'housekeeping' enzyme indicates that LDH might be needed by $M$. hyopneumoniae to achieve certain steps in infection.

We are grateful to M. Solioz, University of Berne, for valuable help with the GCG software packet, to J. Schaller, Dept of Biochemistry, for protein sequence analysis, and to M. Krawinkler for expert technical assistance.

\section{References}

Brooks, E. \& FAULDS, D. (1989). The Mycoplasma hyopneumoniae 74.5-kD antigen elicits neutralizing antibodies and shares sequence similarity with heat-shock proteins. In Vaccines 89, pp. 265-269. Edited by R. A. Lerner, H. Ginsberg, R. M. Chanock \& F. Brown. New York: Cold Spring Harbor Laboratory Press.

Bullock, W. O., Fernandez, J. M. \& Short, J. M. (1987). XLl-blue: a high efficiency plasmid transforming recA $E$. coli strain with betagalactosidase selection. Biotechniques 5, 376-379.

ClYDE, W. A. (1983). Growth inhibition tests. In Methods in Mycoplasmology I, pp. 405-410. Edited by S. Razin \& J. G. Tully. London: Academic Press.

FaIRoz, M.-J., Kiswar, Y. A. \& Clark, D. P. (1989). Mutants of Escherichia coli deficient in the fermentative lactate dehydrogenase. Journal of Bacteriology 171, 342-348.

Ferrell, R. V., Heidari, M. B., Wise, K. S. \& McIntosh, M. A. (1989). A mycoplasma genetic element resembling prokaryotic insertion sequences. Molecular Microbiology 3, 957-967.

FOSTER, J. W. (1991). Salmonella acid shock proteins are required for the adaptive acid tolerance response. Journal of Bacteriology 173, 6896-6902.

FRIS, M. F. (1971). Sensitivity of Mycoplasma suipneumoniae to penicillin-G. Acta Veterinaria Scandinavica 12, 120-121.

GARVIE, E. I. (1980). Bacterial lactate dehydrogenases. Microbiological Reviews 44, 106-139.

GeARY, S. J. \& WaLCZAK, E. M. (1985). Isolation of a cytopathic factor from Mycoplasma hyopneumoniae. Infection and Immunity 48, 576-578.

Harasawa, R., Koshimizu, K., Takeda, O., Uemori, T., Asada, K. \& KATO, I. (1991). Detection of Mycoplasma hyopneumoniae DNA by the polymerase chain reaction. Molecular and Cellular Probes 5, 103-109.

Hediger, M. A., Frank, G. \& Zuber, H. (1986). Structure and function of L-lactate dehydrogenases from thermophilic and mesophilic bacteria, IV: The primary structure of the mesophilic lactate dehydrogenase from Bacillus subtilis. Biological Chemistry Hoppe-Seyler 367, 891-903.

Hensel, R., MaYR, U. \& YANG, C.-Y. (1983). The complete primary structure of the allosteric L-lactate dehydrogenase from Lactobacillus casei. European Journal of Biochemistry 134, 503-511.

HoPP, T. P. \& WoODs, K. R. (1981). Prediction of protein antigenic determinants from amino acid sequences. Proceedings of the National Academy of Sciences of the United States of America 78, 3824-3828.

Kiltz, H.-H., Keil, W., Griesbach, M. \& MeYer, H. (1977). The primary structure of porcine lactate dehydrogenase: Isoenzymes $\mathbf{M}_{4}$ and $\mathrm{H}_{4}$. Hoppe-Seyler's Zeitschrift für Physiologische Chemie 358, $123-127$.

Kim, M. F., Heidari, M. B., Stull, S. J., McIntosh, M. A. \& Wise, K. S. (1990). Identification and mapping of an immunogenic region of Mycoplasma hyopneumoniae p65 surface lipoprotein expressed in Escherichia coli from a cloned genomic fragment. Infection and Immunity 58, 2637-2643.

Klinkert, M.-Q., Taschke, C., Schaller, H. \& Herrmann, R. (1986). Identification of Mycoplasma hyopneumoniae proteins from an Escherichia coli expression library and analysis of transcription and translation signals. In Protein-Carbohydrate Interactions in Biological Systems, pp. 369-374. Edited by D. L. Lark. London: Academic Press.

Kunai, K., Machida, M., Matsuzawa, H. \& Ohta, T. (1986). Nucleotide sequence and characteristics of the gene for L-lactate dehydrogenase of Thermus caldophilus GK24 and the deduced amino acid sequence of the enzyme. European Journal of Biochemistry 160, 433-440.

Manolukas, J. T., Barile, M. F., Chandler, D. K. F. \& Pollack, J. D. (1988). Presence of anaplerotic reactions and transamination, and the absence of the tricarboxylic acid cycle in mollicutes. Journal of General Microbiology 134, 791-800.

MoRi, Y., Hamaoka, T., Sato, S. \& Takeuchi, S. (1988). Immunoblotting analysis of antibody response in swine experimentally inoculated with Mycoplasma hyopneumoniae. Veterinary Immunology and Immunopathology 19, 239-250. 
Needleman, S. B. \& WunsCh, C. D. (1970). A general method applicable to the search for similarities in the amino acid sequence of two proteins. Journal of Molecular Biology 48, 443-453.

Ono, M., Matsuzawa, H. \& Ohta, T. (1990). Nucleotide sequence and characteristics of the gene for L-lactate dehydrogenase of Thermus aquaticus YT-1 and the deduced amino acid sequence of the enzyme. Journal of Biochemistry 107, 21-26.

Rose, D. L., Tully, J. G. \& Wittler, R. G. (1979). Taxonomy of some swine mycoplasmas: Mycoplasma suipneumoniae Goodwin et al. 1965, a later, objective synonym of Mycoplasma hyopneumoniae Mare and Switzer 1965, and the status of Mycoplasma flocculare Meyling and Friis 1972. International Journal of Systematic Bacteriology 29, 83-91.

RosenberG, M. \& CourT, D. (1979). Regulatory sequences involved in the promotion and termination of RNA transcription. Annual Review of Genetics 14, 319-359.

Ross, R. F. (1992). Mycoplasmal diseases. In Diseases of Swine, 7th ed., pp. 537-551. Edited by A. D. Leman, B. E. Straw, W. L. Mengeling, S. D'Allaire \& D. J. Taylor. Ames: Iowa State University Press.

Sakai, I., Sharief, F. S., Pan, Y.-C. E. \& Li, S. S.-L. (1987). The cDNA and protein sequences of human lactate dehydrogenase $B$. Biochemical Journal 248, 933-936.

SAmbrook, J., Fritsch, E. F. \& Maniatis, T. (1989). Molecular Cloning: a Laboratory Manual, 2nd ed. Cold Spring Harbor, NY: Cold Spring Harbor Laboratory Press.

SANGer, F., Nicklen, S. \& Coulsen, A. R. (1977). DNA sequencing with chain-terminating inhibitors. Proceedings of the National Academy of Sciences of the United States of America 74, 5463-5467.

Shine, J. \& Dalgarno, L. (1974). The $3^{\prime}$ terminal sequence of Escherichia coli $16 \mathrm{~S}$ ribosomal RNA: complementarity to nonsense triplets and ribosome binding sites. Proceedings of the National Academy of Sciences of the United States of America 71, 1342-1346.

SloncZeWsKi, J. L., GonZalez, T. N., BaRTHOlOMEW, F. M. \& Holt, N. J. (1987). Mud-directed lac $Z$ fusions regulated by low $\mathrm{pH}$ in Escherichia coli. Journal of Bacteriology 169, 3001-3006.

Stemke, G. W., McIntyre, D. J., Roy, K. L., Stemler, M. E. \& ROBERTSON, J. A. (1985). Guanine-plus-cytosine compositions of, and deoxyribonucleic acid hybridization comparisons between, Mycoplasma hyopneumoniae and Mycoplasma flocculare. International Journal of Systematic Bacteriology 35, 527-529.

Stipkovits, L., Nicolet, J., HaldimanN, A. \& Frey, J. (1991). Use of antibodies against the P36 protein of Mycoplasma hyopneumoniae for the identification of $M$. hyopneumoniae strains. Molecular and Cellular Probes 5, 451-457.

Strasser, M., Frey, J., Bestetti, G., Kobisch, M. \& Nicolet, J. (1991). Cloning and expression of a species-specific early immunogenic 36-kilodalton protein of Mycoplasma hyopneumoniae in Escherichia coli. Infection and Immunity 59, 1217-1222.

TASCHKE, C. \& HeRRMANN, R. (1986). Analysis of transcription and processing signals of the 16S-23S rRNA operon of Mycoplasma hyopneumoniae. Molecular and General Genetics 205, 434-441.

TAschKe, C., KlinkerT, M.-Q., Wolters, J. \& Herrmann, R. (1986). Organization of the ribosomal RNA genes in Mycoplasma hyopneumoniae: The 5S rRNA gene is separated from the 16S and 23S rRNA genes. Molecular and General Genetics 205, 428-433.

Taschke, C., Ruland, K. \& Herrmann, R. (1987). Nucleotide sequence of the 16S rRNA of Mycoplasma hyopneumoniae. Nucleic Acids Research 15, 3918.

TAYLOR-RoBINSON, D. (1983). Metabolism inhibition tests. In Methods in Mycoplasmology I, pp. 411-417. Edited by S. Razin \& J. G. Tully. London: Academic Press.

Tinoco, I., Borer, P. N., Dengler, B., LeVine, M. D., Uhlenbeck, O., Crothers, D. \& Gralla, J. (1973). Improved estimation of secondary structure in ribonucleic acids. Nature, London 246, 40-41.

Tsujibo, H., Tiano, H. F. \& LI, S. S.-L. (1985). Nucleotide sequences of the cDNA and an intronless pseudogene for human lactate dehydrogenase-A isozyme. European Journal of Biochemistry 147, 9-15.

Weisburg, W. G., Tully, J. G., Rose, D. L., Petzel, J. P., Oyaizu, H., Yang, D., Mandelco, L., Sechrest, J., Lawrence, T. G., VaN Etten, J., Maniloff, J. \& Woese, C. R. (1989). A phylogenetic analysis of the mycoplasmas: Basis for their classification. Journal of Bacteriology 171, 6455-6467.

WIRZ, B., SUTER, F. \& ZUBER, H. (1983). Structure and function of Llactate dehydrogenases from thermophilic and mesophilic bacteria, III: The primary structure of thermophilic lactate dehydrogenase from Bacillus stearothermophilus. Hydroxylamine-, o-iodosobenzoic acid- and tryptic-fragments. The complete amino acid sequence. Hoppe-Seyler's Zeitschrift für Physiologische Chemie 364, 893-909.

Yamao, F., Muto, A., Kawauchi, Y., Iwami, M., Iwagami, S., AzUmi, Y. \& Osawa, S. (1985). UGA is read as tryptophan in Mycoplasma capricolum. Proceedings of the National Academy of Sciences of the United States of America 82, 2306-2309.

YounG, T. F. \& Ross, R. F. (1987). Assessment of antibody response of swine infected with Mycoplasma hyopneumoniae by immunoblotting. American Journal of Veterinary Research 48, 651-656.

Zhang, H., Scholl, R., Browse, J. \& Sommerville, C. (1988). Double stranded DNA sequencing as a choice for DNA sequencing. Nucleic Acids Research 16, 1220.

ZüLLI, F., WEBER, H. \& ZUBER, H. (1987). Structure and function of Llactate dehydrogenases from thermophilic and mesophilic bacteria, VI. Nucleotide sequences of lactate dehydrogenase genes from the thermophilic bacteria Bacillus stearothermophilus, B. caldolyticus and B. caldotenax. Biological Chemistry Hoppe-Seyler 368, 1167-1177. 